\title{
СТАТИСТИЧНИЙ ОПИС МЕХАНІЧНИХ ХАРАКТЕРИСТИК СТАЛЕЙ ДЛЯ БУДІВЕЛЬНИХ КОНСТРУКЦЙ
}

\author{
STATISTICAL DESCRIPTION OF MECHANICAL \\ CHARACTERISTICS OF BUILDING STRUCTURE STEEL
}

Пічугін С.Ф., д.т.н., проф. (Національний університет «Полтавська політехніка імені Юрія Кондратюка», м. Полтава)

\section{Pichugin S.F., Dr. Tech. Sc., Professor (National University «Yuri Kondratyuk Poltava Polytechnic», Poltava)}

Виконаний систематизований огляд робіт по проблемі статистичного опису механічних характеристик будівельних сталей. Одержана узагальнена інформація щодо статистичних параметрів межі текучості та тимчасового опору сталей за період з 40-х років ХХ сторіччя до теперішнього часу.. Ці дані призначені для використання у чисельних розрахунках надійності конструкциій. Проаналізовані тенденції змін норм проектування сталевих конструкцій у частині забезпечення нормативних $i$ розрахункових опорів сталей та залучення до иьвого дослідних статистичних даних.

The strength of steel is a crucial parameter of the load-bearing capacity of metal structures. Therefore, an objective assessment of the strength of steel is of great importance for ensuring and calculating the reliability of structures and the proper justification of design standards. The yield strength and other mechanical characteristics of modern steels have a statistical variance, which is well described by normal law, which has been repeatedly confirmed by test data of steel samples. The undoubted relevance of regular statistical studies of steel strength is linked to the constant revision of design standards. Factory tests of steel strength are performed for many years on a large scale, creating a significant array of statistical information. However, there is no common information database for these data. Some of them have been published in various scientific and technical journals, collections of articles, conference proceedings. Access to these publications is difficult. The translation into electronic form has taken place only for publications published after 2000. The article contains a systematic review of publications in leading scientific and technical journals on the problem of statistical description of the strength of construction steels. The main attention is paid to the selection of statistical strength characteristics of steels of different periods, such as mathematical expectation, standard deviation (standard), coefficient of variation, etc. The analysis confirmed the high security of normative and design resistances of rolling profiles made of low-carbon steel brands St3ps and St3sp. In most cases, the requirement to ensure the values of the normative resistance of building materials with a probability of 0.95 for steel grade St 3 is met. It is shown that the provision of the design resistances of rolled steel from St3sp and St3ps steels is always higher than the probability of 0.999. The statistical 
data of mechanical tests results of low-alloy construction steels 14G2, 10G2S1, 15 HSND, 10 HSND and high-strength steels are given. Thermomechanical hardened steels of high purity can be attributed to the third generation of construction steels and used in building metal structures of the most responsible and unique structures. The data presented in the article are intended for use in numerical calculations of structural reliability. In addition, the evolution of design standards for steel structures is analyzed in the sense of justification of normative and design resistances and the involvement of experimental statistics.

Ключові слова: міџність сталі, межа текучості, тимчасовий опір, нормативний опір, розрахунковий опір, коефіџієнт однорідності.

Keywords: strength of steel, yield strength, temporary resistance, normative resistance, design resistance, coefficient of homogeneity.

Вступ. Міцність сталі - це вирішальний параметр несучої здатності будівельних металевих конструкцій. Тому об'єктивне оцінювання міцності сталі має велике значення для забезпечення і розрахунку надійності конструкцій та належного обгрунтування норм проектування. Відомо, що процес виплавки сталі є досить складним і не ідеально контрольованим (висока температура, час процесу плавки, вміст легуючих домішок тощо). Згодом при прокатці відбувається обтискання металу, роздрібнення зерен i різна їхня орієнтація вздовж і поперек прокату, що впливає на механічні властивості металу. На властивості сталі впливають також температура прокатки і подальше охолодження. Крім того, при збільшенні товщини прокату механічні характеристики металу понижуються. При наявності таких численних факторів, що впливають на міцність сталі, цілком природно, що показники міцності мають певну змінність, наочне уявлення про яку дають статистичні криві розподілу різних характеристик сталі. Межа текучості та інші механічні характеристики сучасних сталей мають статистичний розкид, який добре описується нормальним законом, що було неодноразово підтверджено даними випробування зразків сталі. Тому безсумнівна актуальність регулярних статистичних досліджень міцності сталі в ув'язці 3 постійним переглядом норм проектування.

Аналіз результатів досліджень і публікацій. Вихідні дані щодо механічних характеристик сталі одержуються у результаті стандартних приймальних випробувань зразків виплавлених сталей у лабораторіях металургійних заводів. Основне призначення цих даних - оцінювання якості і бракування некондиційної металургійної продукції. Крім того, статистичні результати випробування сталей використовуються при складанні і перегляді норм проектування. Особливо цей процес активізувався 3 введенням методики розрахунку за граничним станами $[1,2]$. Статистичному опису механічних характеристик сталі, зокрема $і i ̈$ 
міцності, присвячені численні публікації вітчизняних дослідників, починаючи 3 40-х років минулого століття [3 - 16]. Активно обговорюють цю проблему закордонні фахівці [17 - 20]. Достовірні статистичні параметри міцності сталі особливо потрібні для оцінювання надійності металевих конструкцій. На цьому наголошується, зокрема, у публікаціях, підготовлених науковою школою «Надійність будівельних конструкцій» Національного університету «Полтавська політехніка імені Юрія Кондратюка» [21 - 24].

Заводські випробування міцності сталі виконуються багато років у великих масштабах, створюючи значний масив статистичної інформації. Однак відсутня загальна інформаційна база цих даних. Деякі з них опубліковані у різноманітних науково-технічних журналах, збірниках статей, матеріалах конференцій. Доступ до цих видань утруднений, тим більше що в деяких установах почали знищувати паперові журнали минулих років, мотивуючи переходом на електронні видання. Однак у реальності переведення в електронну форму відбулося поки тільки для видань, що вийшли після 2000 р.

Мета і задачі дослідження. Стаття містить систематизований огляд публікацій у ведучих науково-технічних журналах по проблемі статистичного опису міцності будівельних сталей. Головна увага приділяється вибірці статистичних характеристик міцності сталей різного періоду, таких як математичне сподівання, середньоквадратичне відхилення (стандарт), коефіцієнт варіації та ін. Ці дані призначені для використання у чисельних розрахунках надійності конструкцій. Крім того, прослідковується еволюція норм проектування сталевих конструкцій у частині змін призначення нормативних і розрахункових опорів та залучення до цього дослідних статистичних даних.

Основний матеріал та результати. Змістом статті $\epsilon$ упорядкований огляд публікацій таких науково-технічних журналів, як «Промислове і цивільне будівництво» (раніше «Будівельна промисловість» та «Промислове будівництво»), «Промислове будівництво та інженерні споруди», «Будівельна механіка і розрахунок споруд», «Вісті ВНЗ. Будівництво та архітектура», «Будівельні матеріали», «Автоматичне зварювання» та ін. Огляд складений за період 3 40-х років XX сторіччя по теперішній час. У паперовому варіанті в основному пророблялися журнали, видані до 2000 р., що знаходилися у науково-технічній бібліотеці Національного університеті «Полтавська політехніка імені Юрія Кондратюка», одному із найповніших книжкових сховищ в Україні. Інформація щодо пізніших видань, переведених у цифрову форму, зібрана з електронних бібліотек та електронних версій журналів. 
Маловуглецева сталь Cm3. Статистичні дослідження міцності маловуглецевої сталі були започатковані ще до Другої світової війни В.В. Кураєвим під керівництвом проф. М.С. Стрілецького [1]. На їх основі було встановлено мінімальне значення межі текучості і допустиме напруження для сталі марки Ст3 $[\sigma]=1600$ кг/см².

3 переходом у 1955 р. розрахунку сталевих конструкцій на методику граничних станів були введені НіТУ 121-55 «Норми і технічні умови проектування сталевих конструкцій». Для сталі марки Ст3 у цих нормах був введений нормативний опір $R^{H}=2400$ кг/см², що дорівнювався бракувальному мінімуму при приймальних випробуваннях зразків сталі за відповідним ГОСТом. Можливість відхилення міцності від нормативного опору у менший бік внаслідок вибірковості контролю та змінності розмірів прокату враховувалося коефіцієнтом однорідності $k=0,9$. Розрахунковий опір на розтяг, стик i згин визначався як $R=k R^{H}=0,9 \cdot 2400=2100$ кг $/ \mathrm{cm}^{2}$. Розрахунковий опір дорівнював мінімальному ймовірному значенню межі текучості сталі, який визначався як

$$
R=\bar{\sigma}_{T}-3 \hat{\sigma}_{T}
$$

де $\bar{\sigma}_{T}$ і $\hat{\sigma}_{T}$ - математичне сподівання $\mathrm{i}$ середньоквадратичне відхилення (стандарт) межі текучості.

Розрахунковий опір визначався на основі статистичної обробки 6 тис. результатів заводських випробувань сталі марки Ст3 різних заводів. [2].

У $60-\mathrm{i}$ роки минулого століття у металургійній промисловості відбулися істотні зміни в виробництві маловуглецевої стали: розвинулася киснево-конвертерна виплавка, освоєні нові схеми розкислення (напівспокійна сталь), зросла потужність мартенівських печей, збільшилася вага злитка. Це відобразилося у наступному виданні норм СНіП ІІ-В.3-62 «Сталеві конструкції. Норми проектування». В них введені два розрахункових опори - за межею текучості $R=2100 \mathrm{\kappa г} / \mathrm{cm}^{2}$ (як раніше) і за тимчасовим опором $R_{p}=2600$ кг/см². Виділені окремо мартенівська і конвертерна сталі, а також ступені розкислення стали: спокійна (сп), кипляча (кп) і напівспокійна (пс).

Згаданий розвиток металургійної технології та перегляд норм проектування здійснили певний вплив на механічні властивості сталей. Тому ЦНДІБК провів статистичну обробку результатів приймальних випробувань мартенівської товстолистової сталі Ст3 по ГОСТ 380-60 товщиною 2 - 60 мм на трьох металургійних заводах: Магнітогорському металургійному комбінаті (ММК), Комунарському металургійному заводі і металургійному заводі ім. Ілліча (Маріуполь) [4]). Одержані результати 
наведені у табл. 1. Дані дослідження показали, що механічні властивості прокатної маловуглецевої стали Ст3 у зазначені роки помітно знизилися (особливо за межею текучості і ударною в'язкістю). Тому був зроблений висновок, що методика приймальних випробувань стали того часу (особливо визначення межі текучості) потребувала суттєвого поліпшення.

3 наведеними у табл. 1 даними ув'язуються опубліковані дещо раніше результати статистичної обробки результатів механічних випробувань сталі ВСт3 різних металургійних підприємств [3]:

- межа текучості: $\bar{\sigma}_{y}=281,0 \mathrm{MПа} ; \hat{\sigma}_{y}=23,4 \mathrm{MПа} ; \sigma_{y \max }=350,0 \mathrm{MПа}$;

- межа міцності: $\bar{\sigma}_{u}=456,4$ МПА; $\hat{\sigma}_{u}=216$ МПа; $\sigma_{u \max }=520,0$ МПа.

Таблиця 1

Статистичні дані щодо механічних характеристик листової сталі Ст3

\begin{tabular}{|c|c|c|c|c|}
\hline \multicolumn{5}{|c|}{ Межа текучості } \\
\hline Сталь & Дата, джерело & $\bar{\sigma}_{y}$, МПа & $\hat{\sigma}_{y}$, МПа & $V_{y}, \%$ \\
\hline \multirow{2}{*}{ СтЗкп } & $1968 \mathrm{p} \mathrm{[4]}$ & $284,1-310,7$ & $21,9-25,7$ & 7,55 \\
\hline & $1980 \mathrm{p} \mathrm{[7]}$ & 266,0 & 29,0 & 10,9 \\
\hline \multirow{2}{*}{ СтЗпс } & $1968 \mathrm{p} \mathrm{[4]}$ & $293,6-312,2$ & $21,5-26,8$ & 7,30 \\
\hline & $1980 \mathrm{p}[7]$ & $265,0-289,0$ & $25,0-30,0$ & 9,9 \\
\hline \multirow{2}{*}{ СтЗсп } & $1968 \mathrm{p} \mathrm{[4]}$ & $232,6-294,0$ & $15,9-25,9$ & $5,8-9,1$ \\
\hline & $1980 \mathrm{p} \mathrm{[г]}$ & $268,0-294,0$ & $22,0-27,0$ & 8,7 \\
\hline \multicolumn{5}{|c|}{ Межа міиності } \\
\hline Сталь & Дата, джерело & $\bar{\sigma}_{u}$, МПа & $\hat{\sigma}_{u}$, МПа & $V_{u}, \%$ \\
\hline \multirow{2}{*}{ СтЗкп } & $1968 \mathrm{p}[4]$ & $422,4-433,0$ & $23,4-29,1$ & 5,83 \\
\hline & 1980 p [7] & 410,0 & 30,0 & 7,32 \\
\hline \multirow[b]{2}{*}{ СтЗпс } & $1968 \mathrm{p} \mathrm{[4]}$ & $441,8-436,0$ & $20,6-27,1$ & 4,75 \\
\hline & $1980 \mathrm{p}[7]$ & $420,0-437,0$ & $25,0-27,0$ & 6,07 \\
\hline \multirow{2}{*}{ Ст3сп } & $1968 \mathrm{p} \mathrm{[4]}$ & $417,0-459,0$ & $19,2-23,4$ & 5,54 \\
\hline & $1980 \mathrm{p} \mathrm{[7]}$ & $433,0-440,0$ & $20,0-25,0$ & 5,15 \\
\hline \multicolumn{5}{|c|}{$\begin{array}{l}\text { Позначення: } \bar{\sigma}_{y}, \hat{\sigma}_{y}, V_{y}-\text { відповідно середнє значення, стандарт } \\
\text { коефіцієнт варіації межі текучості; } \bar{\sigma}_{u}, \hat{\sigma}_{u}, V_{u}-\text { те ж межі міцност } \\
\text { (тимчасового опору). }\end{array}$} \\
\hline
\end{tabular}

Відомо, що у випадках, коли результати контрольних випробувань відповідають нормам ГОСТ і ТУ, споживач може одержати метал із значеннями міцнісних характеристик нижче нормативних опорів. У статті [5] виконаний ймовірнісний аналіз цих відхилень, які враховуються у нормах коефіцієнтом однорідності (коефіцієнтом надійності за матеріалом). 
Готуючи черговий перегляд норм сталевих конструкцій, у кінці 70-х років ЦНІДБК провів масштабне оброблення даних 26 тис. приймальних випробувань сталі Ст3 (публікація 1980 р [7]), результати якого частково наведені у табл. 1. Вони в цілому відповідають результатам раніше виконаних випробувань і підтверджують менший статистичний розкид даних щодо межи міцності у порівнянні з межею текучості. Одержаний масив статистичної інформації був ув'язаний з основними положеннями розрахунку сталевих конструкцій за граничними станами. Зокрема, було проведено оцінювання імовірнісної забезпеченості нормативних i розрахункових опорів сталі Ст3 (табл. 2).

Таблиця 2

Забезпеченість нормативних і розрахункових опорів сталі Ст3

\begin{tabular}{|c|c|c|c|c|c|c|c|}
\hline \multirow{3}{*}{$\begin{array}{l}\text { Про- } \\
\text { філь }\end{array}$} & \multirow{3}{*}{ Сталь } & \multicolumn{2}{|c|}{ Нормативний опір } & \multicolumn{4}{|c|}{ Розрахунковий опір } \\
\hline & & \multirow[t]{2}{*}{$P\left(R_{y n}\right)$} & \multirow[t]{2}{*}{$P\left(R_{u n}\right)$} & \multicolumn{2}{|c|}{$\begin{array}{l}\text { За межею } \\
\text { текучості }\end{array}$} & \multicolumn{2}{|c|}{$\begin{array}{c}\text { За межею } \\
\text { міцності }\end{array}$} \\
\hline & & & & $\gamma_{y}$ & $P\left(R_{y}\right)$ & $\gamma_{u}$ & $P\left(R_{u}\right)$ \\
\hline \multirow{3}{*}{ Лист } & Ст3кп & 0,893 & 0,841 & 1,94 & 0,974 & 5,00 & $\approx 1$ \\
\hline & Ст3пс & $\begin{array}{c}0,894- \\
0,991\end{array}$ & $\begin{array}{c}0,929- \\
0,989\end{array}$ & $\begin{array}{l}1,97- \\
3,12\end{array}$ & $\begin{array}{l}0,976- \\
0,9986\end{array}$ & $\begin{array}{l}5,92- \\
7,07\end{array}$ & $\approx 1$ \\
\hline & Ст3сп & $\begin{array}{c}0,921- \\
0,998\end{array}$ & $\begin{array}{c}0,984- \\
0,996 \\
\end{array}$ & $\begin{array}{l}2,15- \\
3,82\end{array}$ & $\begin{array}{l}0,984- \\
0,9999\end{array}$ & $\begin{array}{l}6,96- \\
8,65\end{array}$ & $\approx 1$ \\
\hline \multirow{3}{*}{$\begin{array}{l}\text { Сталь } \\
\text { куто- } \\
\text { ва }\end{array}$} & Ст3кп & 0,989 & 0,913 & 3,09 & 0,999 & 5,65 & $\approx 1$ \\
\hline & Ст3пс & 0,999 & 0,985 & 4,05 & 0,99997 & 7,72 & $\approx 1$ \\
\hline & Ст3сп & 0,999 & 0,993 & 3,92 & 0,9998 & 7,07 & $\approx 1$ \\
\hline \multirow{3}{*}{$\begin{array}{l}\text { Шве- } \\
\text { лери, } \\
\text { балки }\end{array}$} & Ст3кп & 0,999 & 0,985 & 4,04 & 0,99997 & 7,95 & $\approx 1$ \\
\hline & Ст3пс & 0,9999 & 0,9996 & 5,24 & $\approx 1$ & 8,95 & $\approx 1$ \\
\hline & Ст3сп & 0,9999 & 0,999 & 5,67 & $\approx 1$ & 6,46 & $\approx 1$ \\
\hline
\end{tabular}

Аналіз даних табл. 2 дозволив обгрунтувати наступні висновки:

- невисокою $є$ забезпеченість нормативних опорів листового прокату товщиною до 10 мм із сталей СтЗпс і СтЗкп, що пояснюється істотною часткою менш міцної рулонної стали;

- висока забезпеченість нормативних опорів $R_{y n}$ і $R_{u n}$ кутової сталі, швелерів і балок зі сталі марок Ст3пс і Ст3сп; 
- вимога про забезпеченість значень нормативних опорів будівельних матеріалів 3 ймовірністю 0,95 для стали Ст3 в більшості випадків виконується;

- більш високою $є$ забезпеченість значень розрахункових опорів за межею міцності, для яких забезпеченість у всіх випадках близька до $P \approx 1,00$, а характеристика безпеки $\gamma=5-9$;

- забезпеченість розрахункових опорів профільного прокату із сталей Ст3сп і Ст3пс завжди вище ймовірності 0,999, при цьому характеристика безпеки $\gamma=4-6$. Тому ЦНДІБК запропонував підвищити розрахункові опори ВСт3сп до 230 МПа і ВСт3кп до 220 МПа, що було реалізовано при переробленні норм проектування.

У новому виданні норм СНіП ІІ-23-81 «Сталеві конструкції» для сталі Ст3 були введені дві групи міцності (за пропозицією Інституту електрозварювання імені С.О. Патона), марки замінені на класи (сталь Ст3 була віднесена до класів С235, С245 і С255 в залежності від степені розкислення і груп міцності), введена диференціація в залежності від виду прокату (листовий або фасонний) i товщини профілів. Для переходу від нормативного опору до розрахункового замість коефіцієнту однорідності тепер застосовувався коефіцієнт надійності за матеріалом $\gamma_{m}$ :

$$
R_{y}=R_{y n} / \gamma_{m} ; \quad R_{u}=R_{u n} / \gamma_{m},
$$

де $R_{y n}, R_{u n}-$ нормативні опори відповідно за межею текучості $\mathrm{i}$ тимчасовим опором; $R_{y}, R_{u}$ - аналогічні розрахункові опори.

Обгрунтовані статистично нові коефіцієнти надійності за матеріалом несуттєво відрізняються від одиниці: $\gamma_{m}=1,025-1,100$.

Стаття співробітників ЦНДІБК [8] підвела підсумки перших років впровадження СНіП II-23-81, яке призвело до суттєвої економії сталі у будівництві. Наступні видання норм України ДБН В.2.6-198:2014 «Сталеві конструкції. Норми проектування» і Росії СП 16.13330.2017 «СНіП ІІ-23-81*» не відрізняються принципово від СНіП ІІ-23-81 у частині нормування міцності будівельних сталей [16].

За останній період розширилося застосування легких тонкостінних сталевих конструкцій. При цьому було встановлено, що холодне формування сталевих профілів призводить до їх зміцнення. Для виявлення його була виконана статистична обробка результатів випробувань зразків 3 двох сталей [9]. Отриманий фактор зміцнення добре описується нормальним законом і має наступні параметри:

$$
\begin{aligned}
& \text { - } 14 Г 2-\bar{m}=1,17, \hat{m}=0,082, V=6,4 \% ; \\
& \text { - } \quad \text { ВСт } 3 \text { сп - } \bar{m}=1,31, \hat{m}=0,066, V=5,0 \% .
\end{aligned}
$$


Низьколеговані сталі. Невипадково, що статистичні дослідження властивостей маловуглецевої сталі звичайної міцності були самими масштабними. За даними на кінець $80-\mathrm{x}$ років для виготовлення будівельних сталевих конструкцій використовувалися $80 \%$ прокату саме такої сталі 3 межею текучості до 245 МПа. Низьколеговані сталі підвищеної міцності з межею текучості 325 - 345 МПа складали $15 \%$, прокат сталей високої міцності з межею текучості не менше 390 МПа всього 5\% [8]. Тому актуальним було розгортання досліджень саме сталей підвищеної та високої міцності.

Ще у післявоєнні 1955 - 1957 pp. Челябінський завод металоконструкцій виконав масштабні статистичні механічні випробування природно-легованої сталі НЛ2 (15ХСНД) (30 тис. т), поставленої ММК, Кузнецьким металургійним комбінатом (КМК), Нижньо-Тагильським металургійним заводом (НТМЗ) та заводом імені Дзержинського [10]. Розподіл межі текучості сталі НЛ2 був добре описаний нормальним законом із характеристиками $\bar{\sigma}_{y}=382,0$ МПа; $\hat{\sigma}_{y}=27,3$ МПа. Автор публікації, відомий фахівець Б.І. Беляєв підрахував за авторською методикою коефіцієнт однорідності $K_{c p}=0,757$ 3 урахуванням мінусових допусків на розміри перерізів прокатних профілів, що дало наступне значення розрахункового опору сталі НЛ2 (15ХСНД):

$$
R=K_{c p} \bar{\sigma}_{y}=0,767 \cdot 382 \approx 290 \text { МПа. }
$$

Тому був зроблений обгрунтований висновок, що прийнятий у тодішніх нормах НіТУ 121-55 розрахунковий опір 290 МПа знаходиться у повній відповідності із фактичними механічними властивостями сталі НЛ2. Разом з цим Б.І. Беляєв піддав критиці систему бракування цієї сталі, оскільки тодішній бракувальний мінімум 340 МПа знаходився на відстані 1,43 стандарту від середнього значення, що призводило до ймовірного бракування 7,6\% сталі. Тому автором статті було запропоновано прийняти бракувальний мінімум на рівні 3 стандартів, тобто $382-3 \cdot 27,3=300$ МПа.

У середині 60-х років була виконана статистична обробка результатів механічних випробувань низьколегованих будівельних сталей 14Г2, 15 ХСНД, 10 ХСНД у кількості відповідно 225, 575 и 507 заводських випробувань на ММК, НТМЗ, КМК, Орсько-Халіловському (ОХМК) та інших металургійних підприємствах [3]. Одержані результати зведені у табл. 3, дані якої щодо сталі 15ХСНД відрізняються від попередніх [10] більшим стандартом - 34,5 МПа у порівнянні з 27,3 МПа при однакових середніх значеннях. 
Таблиця 3 Статистичні дані щодо механічних характеристик низьколегованих сталей

\begin{tabular}{|c|c|c|c|c|c|c|}
\hline \multirow{2}{*}{$\begin{array}{c}\text { Марка } \\
\text { сталі }\end{array}$} & \multicolumn{2}{|c|}{ Межа текучості $\sigma_{y}$, МПа } & \multicolumn{3}{|c|}{ Межа міцності $\sigma_{u}$, МПа } \\
\cline { 2 - 7 } & $\bar{\sigma}_{y}$ & $\hat{\sigma}_{y}$ & $\sigma_{y \max }$ & $\bar{\sigma}_{u}$ & $\hat{\sigma}_{u}$ & $\sigma_{y \max }$ \\
\hline $14 Г 2$ & 398,8 & 36,0 & 510,0 & 552,0 & 38,6 & 670,0 \\
\hline 15 ХСНД & 389,2 & 34,5 & 500,0 & 562,4 & 30,0 & 660,0 \\
\hline 10 ХСНД & 458,7 & 37,6 & 580,0 & 597,5 & 34,6 & 710,0 \\
\hline
\end{tabular}

Детальне статистичне дослідження низьколегованої сталі 10 Г2С1 провів у кінці 60-х років Б.Ю. Уваров на металургійному заводі імені Ілліча (Маріуполь) [11]. Досліджувалися листи товщиною 26 - 119 мм, кількість зразків складала 1200. Криві розподілу механічних характеристик були близькі до нормальних з невеликою асиметрією.

Було виявлено зменшення механічних характеристик сталі зі збільшенням товщини листа. Ця загальна тенденція була описана наступними рівняннями регресії:

- $\quad$ для середніх значень:

$$
\begin{aligned}
& \bar{\sigma}_{y}=41,3-0,085 \delta ; \bar{\sigma}_{u}=56,5-0,039 \delta ; \bar{\delta}_{5}=27,7-0,019 \delta \text {; } \\
& \text { - для стандарту: } \\
& \hat{\sigma}_{y}=2,67-0,006 \delta ; \hat{\sigma}_{u}=2,70-0,014 \delta ; \hat{\delta}_{5}=2,29-0,007 \delta .
\end{aligned}
$$

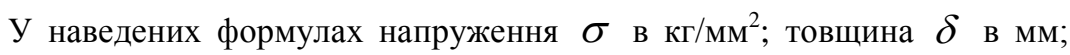
відносне видовження $\delta_{5}$ у $\%$.

Стандарти межі текучості і міцності зі збільшенням товщини зменшуються внаслідок вирівнювання механічних властивостей при повільному охолодженні більш товстих листів.

Коефіцієнт однорідності визначався звичайним чином

$$
k=\frac{1-\gamma \sqrt{V_{y}^{2}+V_{f}^{2}}}{1-\gamma^{2} V_{f}^{2}},
$$

де $\gamma$ - коефіцієнт безпеки (прийнятий в нормах рівним 3); $V_{y}$ - коефіцієнт варіації межі текучості; $V_{f}=0,043$ - коефіцієнт варіації за площею.

Після підстановки в формулу числових значень було обчислено коефіцієнт однорідності $k=0,79$ За рівнянням лінії регресії була одержана формула для розрахункового опору

$$
R=32,6-0,068 \delta \text {. }
$$


Було показано, що при збільшенні товщини листа на кожні 15 мм розрахунковий опір зменшується на 10 МПа. Це було враховано у табл. 4. Рекомендований розподіл листового прокату на групи, більш вузькі ніж у нормах, міг дати певний економічний ефект, але не був повністю впроваджений.

Таблиця 4

Рекомендовані розрахункові опори листової сталі 10Г2С1

\begin{tabular}{|c|c|c|c|c|c|c|}
\hline $\begin{array}{c}\text { Товщина, } \\
\text { мм }\end{array}$ & До 38 & $39-52$ & $53-68$ & $69-82$ & $83-98$ & $99-110$ \\
\hline$R$, МПа & 300 & 290 & 280 & 270 & 260 & 250 \\
\hline
\end{tabular}

На початку 80-х років фахівці Московського інженерно-будівельного інституту (МІБІ) провели статистичні дослідження високоміцних сталей [12]. Дані щодо сталі 12 ГН2МФАЮ класу міцності С70/60 були одержані за результатами приймально-здавальних випробувань на ОХМК, обсяг вибірки - 4 тисячі випробувань. Випробовувався листовий прокат завтовшки 12 - 40 мм. Одержані результати: середнє значення межі текучості $\bar{\sigma}_{y}=710,4$ МПа; межі міцності $\bar{\sigma}_{u}=806,4$ МПа; середнє відносне видовження $\bar{\delta}_{5}=16,11 \%$. Сталь всередині партії неоднорідна (випробувані 327 партій): стандарт розподілу властивостей всередині партії в частках стандарту генерального розподілу становить: 0,53 за межею текучості і 0,48 за межею міцності. Досліджений прокат задовольняє вимогам для сталі класу С70/60: $\sigma_{y} \geq 60 \mathrm{MПа;}$ $\sigma_{u} \geq 70 \mathrm{MПа;} \delta_{5} \geq 12 \%$. За результатами випробувань високоміцну сталь марки 12ГН2МФАЮ можна вважати перспективною для відповідальних зварних металоконструкцій, що працюють під динамічними навантаженнями i експлуатуються при негативних температурах нижче $-40^{\circ} \mathrm{C}$.

Статистичний аналіз властивостей нової високоміцної сталі 3

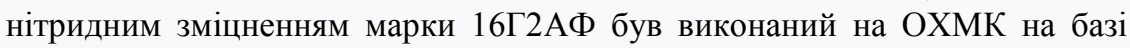
вибірки з 6,5 тисяч випробувань [13]. Випробувався листовий прокат товщиною 10 - 40 мм. Сталь у нормализованому стані мала середнє значення межі текучості $\bar{\sigma}_{y}=470 \mathrm{MПа;} \mathrm{межі} \mathrm{міцності} \bar{\sigma}_{u}=650$ МПа. Термічно оброблена сталь мала дещо вищі характеристики - середнє значення межі текучості $\bar{\sigma}_{y}=550 \mathrm{MПа;} \mathrm{межі} \mathrm{міцності} \bar{\sigma}_{u}=680$ МПа. Сталь всередині партії неоднорідна (випробовувалися 816 партій): стандарт розподілу властивостей нормалізованої сталі всередині партії в частках стандарту генерального розподілу становить: 0,518 за межею текучості і 0,607 за межею міцності. Був зроблений висновок, що 
розроблена сталь як по міцності, так і по пластичним характеристикам відповідає вимогам, що пред'являються до сталей високої міцності.

У публікаціях останніх років описані нові високоміцні стали великої товщини $[14,15]$. Прокат сталей С 345, C 375, C390 і С440 володіє високими інженерними властивостями i хорошою зварюваністю. Термомеханічні зміцнені стали високої чистоти можуть бути віднесені до третього покоління будівельних сталей і застосовуватися в будівельних металоконструкціях найбільш відповідальних і унікальних споруд.

Висновки. Виконаний систематизований огляд робіт по проблемі статистичного опису міцності будівельних сталей. Головна увага приділена вибірці статистичних характеристик міцності маловуглецевих та низьколегованих сталей за 80-річний період часу, таких як математичне сподівання, середньоквадратичне відхилення (стандарт), коефіцієнт варіації та ін. Ці дані призначені для використання у чисельних розрахунках надійності конструкцій. Проаналізована еволюція норм проектування сталевих конструкцій у частині змін призначення і забезпечення нормативних і розрахункових опорів та залучення до цього дослідних статистичних даних щодо міцності сталей.

\section{References}

1. Streletskiy N.S. K voprosu opredeleniya dopuskayemykh napryazheniy // Stroitel'naya promyshlennost'. - 1940. - №7. - S. 28 - 35. 2. Baldin V.A. Raschet stal'nykh konstruktsíy po predel'nym sostoyaniyam // Materialy mezhdunarodnogo soveshchaniya po raschetu stroitel'nykh konstruktsiy (Moskva, dekabr' 1958 g.). - M.: Gosstroyizdat, 1961. - S. 221 - 233. 3. Chernova M.P. Statisticheskiye issledovaniya nekotorykh tekhnologicheskikh svoystv stroitel'nykh staley // Izvestiya vuzov. Stroitel'stvo i arkhitektura. - 1965.- № 9. - S. 3 - 9. 4. Sokolovskiy P.I. Kachestvo sovremennoy malouglerodistoy stali St.3 // Promyshlennoye stroitel'stvo. - 1968. - №1. - S. 41 - 44. 5. Arone R.G., Uritskiy M.R. Obespechennost' normativnykh i raschetnykh soprotivleniy v stroitel'nykh stalyakh // Stroitel'naya mekhanika i raschet sooruzheniy. 1970. - №3. - S. 35 - 39. 6. Baldin V.A., Uritskiy M.R. Obespechennost' normativnykh i raschetnykh soprotivleniy malouglerodistoy stali dlya stroitel'nykh metallokonstruktsiy // Promyshlennoye stroitel'stvo. - 1978. - №6. - S. 19 - 21. 7. Baldin V.A., Bel'skiy G.Ye. Osnovnyye polozheniya rascheta stal'nykh konstruktsiy po predel'nym sostoyaniyam // Izvestiya vuzov. Stroitel'stvo i arkhitektura. - 1980. - № 11. - S. 3 - 21. 8. Skladnev N.N., Gorpinchenko V.M., Odesskiy P.D., Uritskiy M.R. Snizheniye metalloyemkosti stal'nykh konstruktsiy putem sovershenstvovaniya normativnykh dokumentov // Stroitel'naya mekhanika i raschet sooruzheniy. - 1987. - №5. - S. 6 - 9. 9. Belyayev V.F., Gladshteyn L.I., Artikov G.A. Vybor raschetnykh soprotivleniy stali zamknutykh gnutosvarnykh profiley // Promyshlennoye i grazhdanskoye stroitel'stvo.- 1995. - №5. S. 30 - 32. 10. Belyayev B.I. O raschetnom soprotivlenii dlya prokatnoy stali marki NL2 (15KHSND) // Promyshlennoye stroitel'stvo. - 1960. - №1. - S. 35- 36. 11. Uvarov B.YU. Statisticheskiy analiz rezul'tatov ispytaniya listovoy stali 10G2S1 // Promyshlennoye stroitel'stvo. - 1969. -№3. - S. 30 - 31. 12. Mukhanov K.K., Ishmeneva L.N. Statisticheskiy analiz svoystv vysokoprochnoy stali marki 
12GN2MFAYU // Izvestiya vuzov. Stroitel'stvo i arkhitektura. - 1981. - № 4. - S. 133 136. 13. Ishmeneva L.N. Statisticheskiy analiz svoystv vysokoprochnoy stali s nitridnym uprochneniyem marki 16G2AF // Izvestiya vuzov. Stroitel'stvo i arkhitektura. - 1983. № 7. - S. 14 - 18. 14. Vedyakov I.I., Odesskiy P.D. Stali tret'yego pokoleniya dlya stroitel'nykh metallicheskikh konstruktsiy // Promyshlennoye i grazhdanskoye stroitel'stvo. - 2013. - №7. - S. 23 - 28. 15. Vedyakov I.I., Odesskiy P.D., Forkhaym K., Kulik V.YU. O primenenii novykh staley v unikal'nykh metallicheskikh konstruktsiyakh // Promyshlennoye i grazhdanskoye stroitel'stvo. - 2011. - №6. - S. 66 - 70. 16. Vedyakov I.I., Odesskiy P.D., Gurov S.V. O normirovanii materialov v novom svode pravil SP 16.13330.2017 «SNiP II-32-81* Stal'nyye konstruktsii»// Promyshlennoye i grazhdanskoye stroitel'stvo. - 2018. - №8. - S. 61 - 69. 17. Sadowski A.J., Rotter J.M., Reinke T, Ummenhofer T. Statistical analysis of the material properties of selected structural carbon steels // Structural Safety. - 2015. - 3C. - Pp. 26 - 35. DOI: http://dx.doi.org/10.1016/j.strusafe.2014.12.00. 18. Schmidt B.J. \& Bartlett F.M. Review of resistance factor for steel: resistances distributions and resistance factor calibration // Canadian Journal of Civil Engineering. - 2003. - 29. - Pp. 109 - 118. 19. Melcher J., Kala Z., Holický M., Fajkus M. \& Rozlívka L. Design characteristics of structural steels based on statistical analysis of metallurgical products // Journal of Constructional Steel Research. - 2004. - 60 - Pp. 795 - 808. 20. Agostoni N., Ballio G. $\&$ Poggi C. Statistical analysis of the mechanical properties of structural steel. Costruzioni Metalliche. - 1994. - 2. - Pp. 31 - 39. 21. Perelmuter A.V., Pichugin S.F. On One Safety Characteristic of Buildings // Journal of Civil Engineering and Architecture Research. - Los Angeles, USA: Ethan Publishing Company - 2017. - Vol. 4, No. 5. - Pp. 2035 - 2044. 22. Pichugin S.F. Reliability Estimation of Industrial Building Structures // Magazine of Civil Engineering. - 2018. - 83(7). - Pp. 24 - 37. DOI: 10.18720/MCE.83.3. 23. Pichugin S.F. Scientific School «Reliability of Building structures»: new results and perspectives // Academic Journal. Series: Industrial Machine Building, Civil Engineering. - 2019. - 2(53). - Pp. 5 - 12. https://doi.org/10.26906/znp.2019.53.1880. 24. Pichugin S.F., Makhinko N.A. Highstrength steel grades application for silos structures // Academic Journal. Series: Industrial Machine Building, Civil Engineering. - 2019. - 1(52). - Pp. 51 - 57. https://doi.org/10.26906/znp. 2019.52.1674.

\section{Список використаної літератури}

1. Стрелецкий Н.С. К вопросу определения допускаемых напряжений // Строительная промышленность. - 1940. - №7. - С. 28 - 35. 2. Балдин В.А. Расчет стальных конструкцій по предельным состояниям // Материалы международного совещания по расчету строительных конструкций (Москва, декабрь 1958 г.). - М.: Госстройиздат, 1961. - С. 221 - 233. 3. Чернова М.П. Статистические исследования некоторых технологических свойств строительных сталей // Известия вузов. Строительство и архитектура. - 1965.- № 9. - С. 3 - 9. 4. Соколовский П.И. Качество современной малоуглеродистой стали Ст.3 // Промышленное строительство. - 1968. - №1. - С. 41 - 44. 5. Ароне Р.Г., Урицкий М.Р. Обеспеченность нормативных и расчетных сопротивлений в строительных сталях // Строительная механика и расчет сооружений. - 1970. - №3. - С. 35 - 39. 6. Балдин В.А., Урицкий М.Р. Обеспеченность нормативных и расчетных сопротивлений малоуглеродистой стали для строительных металлоконструкций // Промышленное строительство. - 1978. - №6. - С. 19 - 21. 7. Балдин В.А., Бельский 
Г.Е. Основные положения расчета стальных конструкций по предельным состояниям // Известия вузов. Строительство и архитектура. - 1980. - № 11. С. 3 - 21. 8. Складнев Н.Н., Горпинченко В.М., Одесский П.Д., Урицкий М.Р. Снижение металлоемкости стальных конструкций путем совершенствования нормативных документов // Строительная механика и расчет сооружений. - 1987. №5. - С. 6 - 9. 9. Беляев В.Ф., Гладштейн Л.И., Артиков Г.А. Выбор расчетных сопротивлений стали замкнутых гнутосварных профилей // Промышленное и гражданское строительство.- 1995. - №5. - С. 30 - 32. 10. Беляев Б.И. О расчетном сопротивлении для прокатной стали марки НЛ2 (15ХСНД) // Промышленное строительство. - 1960. - №1. - С. 35- 36. 11. Уваров Б.Ю. Статистический анализ результатов испытания листовой стали 10Г2С1 // Промышленное строительство. 1969. -№3. - С. 30 - 31. 12. Муханов К.К., Ишменева Л.Н. Статистический анализ свойств высокопрочной стали марки 12ГН2МФАЮ // Известия вузов. Строительство и архитектура. - 1981. - № 4. - С. 133 - 136. 13. Ишменева Л.Н. Статистический анализ свойств высокопрочной стали с нитридным упрочнением марки 16Г2АФ // Известия вузов. Строительство и архитектура. - 1983. - № 7. - С. 14 - 18. 14. Ведяков И.И., Одесский П.Д. Стали третьего поколения для строительных металлических конструкций // Промышленное и гражданское строительство. - 2013. - №7. - С. 23 - 28. 15. Ведяков И.И., Одесский П.Д., Форхайм К., Кулик В.Ю. О применении новых сталей в уникальных металлических конструкциях // Промышленное и гражданское строительство. 2011. - №6. - С. 66 - 70. 16. Ведяков И.И., Одесский П.Д., Гуров С.В. О нормировании материалов в новом своде правил СП 16.13330.2017 «СНиП ІІ-3281* Стальные конструкции»// Промышленное и гражданское строительство. 2018. - №8. - C. 61 - 69. 17. Sadowski A.J., Rotter J.M., Reinke T, Ummenhofer T. Statistical analysis of the material properties of selected structural carbon steels // Structural Safety. - 2015. - 3C. - Pp. $26-35$. DOI: http://dx.doi.org/10.1016/j.strusafe.2014.12.00. 18. Schmidt B.J. \& Bartlett F.M. Review of resistance factor for steel: resistances distributions and resistance factor calibration // Canadian Journal of Civil Engineering. - 2003. - 29. - Pp. 109 - 118. 19. Melcher J., Kala Z., Holický M., Fajkus M. \& Rozlívka L. Design characteristics of structural steels based on statistical analysis of metallurgical products // Journal of Constructional Steel Research. - 2004. - 60 - Pp. 795 - 808. 20. Agostoni N., Ballio G. \& Poggi C. Statistical analysis of the mechanical properties of structural steel. - Costruzioni Metalliche. 1994. - 2. - Pp. 31 - 39. 21. Perelmuter A.V., Pichugin S.F. On One Safety Characteristic of Buildings // Journal of Civil Engineering and Architecture Research. Los Angeles, USA: Ethan Publishing Company - 2017. - Vol. 4, No. 5. - Pp. 2035 2044. 22. Pichugin S.F. Reliability Estimation of Industrial Building Structures // Magazine of Civil Engineering. - 2018. - 83(7). - Pp. 24 - 37. DOI: 10.18720/MCE.83.3. 23. Pichugin S.F. Scientific School «Reliability of Building structures»: new results and perspectives // Academic Journal. Series: Industrial Machine Building, Civil Engineering. - 2019. - 2(53). - Pp. 5 - 12. https://doi.org/10.26906/znp.2019.53.1880. 24. Pichugin S.F., Makhinko N.A. Highstrength steel grades application for silos structures // Academic Journal. Series: Industrial Machine Building, Civil Engineering. - 2019. - 1(52). - Pp. 51 - 57. https://doi.org/10.26906/znp. 2019.52.1674. 